\title{
Global + local $=$ glocal public health
}

The WHO Healthy Cities will be 15 years old in the year 2000. It has proved an exceptionally sustainable WHO initiative and is still experiencing growth around the globe. This is all the more noteworthy because the world has changed significantly since the time when the Healthy Cities project was first launched in Europe in $1986 .{ }^{1}$ The initial project was driven by two key ideas: the rediscovery of the importance and potential of local public health and the linking of cities from around Europe into a network with a common purpose. At present the interest and discourse has shifted from the "local" to the "global". Does this mean that the global now dominates the local? Or can the local respond adequately to global pressures? What can Healthy Cities contribute to this debate?

\section{Globalisation and the local}

There is now an ever increasing literature on globalisation. There was a tendency in the early debates to either forget or disregard the local, or to see globalisation as a colonising process or homogenising force against which the local is passive and helpless. The more recent debate underlines the intense interaction between the global and the local. An excellent starting point for this more complex view is the recent Reith Lecture series by Anthony Giddens. He argues that, while globalisation is a distinct reality and a qualitatively new occurrence, it is not only something "out there" in another sphere of action, but has taken root "in here" in our everyday lives. ${ }^{2}$ Globalisation changes our experience of time and place as well as our value base and effects our day to day actions through the economic, political and cultural spheres. A recent issue of the journal Development explores the relation between "Globalism and the politics of place" and illustrates how the global aims to capture locally diverse markets and how creatively the local responds. ${ }^{3}$ This constant interaction is best expressed through the Japanese term "Glocalisation" which Roland Robertson has introduced to the English speaking debate. ${ }^{4}$ While there is a constant shaping of the local from the "outside" through globalisation processes, globalisation in turn makes possible a constant and diverse reinterpretation of these influences and gives the local a voice on the global stage. Indeed "glocalisation" has proved to be a key strategy for global marketing, which expresses itself both in homogeneity (MacWorld) and in the search for ever increasing diversification.

A dominant theme in the globalisation debate has been the discussion of how these processes effect the sovereignty of nation states and their capacity to act. Wolfgang Reinicke argues that while countries keep their legal sovereignty they lose parts of their operational sovereignty. ${ }^{5}$ This means they lose some of the ability to independently conduct public policy: to provide public goods and act in the public interest. Less attention has been given to what Manuel Castels calls the new geometry of power: "the era of globalization of the economy is also the era of localization of polity". ${ }^{6}$ While globalisation produces a polarisation between global elites with disregard for time and space and a local "underclass"-it also enables the creation of a common awareness and joint action across continents through transnational social movements and coalitions for change. ${ }^{7}$ The strong interest of local authorities in networks such as Agenda 21, Healthy Cities or similar projects that link the local and the global can be seen as an expression to counteract political fragmentation and have a voice in global agenda setting.

\section{Healthy cities: key innovations}

Usually the examples that illustrate the interaction of the local and the global come from the sustainable development arena. The Healthy Cities experience should be shared much more forcefully at international level as an excellent illustration of how global and local policy agendas can come together and reinforce one another. Healthy Cities has shown strategic foresight and demonstrated innovation along three dimensions:

THE RELATION BETWEEN THE LOCAL AND THE GLOBAL Healthy Cities demonstrates how a global vision for health can become real at the local level and can in turn be significantly strengthened because of this local base. I propose to also use the term "glocal" for this approach to establish a global identity and sense of purpose, while maintaining diversity. While initiated by an international organisation with set rules of procedure, Healthy Cities has developed its own form of horizontal governance with significant differences around the world. It now represents a new kind of policy alliance beyond the nation state and beyond international organisations. It shows how "those who might be committed to a defense of place . . .create other types of networks .... So that places also gain greater control over their lives and the decisions that matter". ${ }^{3}$ Healthy Cities was not only one of the first UN initiatives to seriously focus on the politics of place, it also recognised the significance of networking local governments-a radical departure not only for the work of the UN as a whole but also for the work of WHO. Healthy Cities brought health into the political arena of city parliaments and became the spearhead of a new public health approach - the settings approach - that is now universally recognised. Indeed, to quote Manuel Castels, it reinforced the "localisation of polity" and illustrates his point that what cities "lack in power and resources they make up in flexibility and networking".

THE NETWORK AS A FORM OF GOVERNANCE

Healthy Cities was one of the first UN projects to understand the importance of networking and it developed new procedures for how to create common commitment and joint accountability - an approach that is now considered by many global strategists as the only way forward in the process of globalisation. I quote: "The network is emerging as the signature form of Organization in the Information age, just as bureaucracy stamped the industrial age, hierarchy controlled the pre-industrial era and the small group roamed in the nomadic era."

Healthy Cities fully complies with the five organising principles of networks as put forward by Lipnack and Stamps:

- Unifying purpose

- Independent members

- Voluntary links

- Multiple leaders

- Integrated levels of action

Manuel Castels goes even further to see the "network society" as the new social structure for the information age. Much of Healthy Cities work is networking: at the local, national and international level. The construct of a "healthy cities project office" as suggested in the Healthy Cities guidelines follows the line of thought that political institutions have become bargaining agencies rather than sites of power. Healthy Cities aimed to build an organisation that mediates, enables and advocates for 
health. Some political scientists and economists increasingly see the role of governments - at all levels - as to ensure social integration and common purpose and to support social cohesion and trust. The network of networks that Healthy Cities creates at the local level is a significant contribution to the creation of social capital and increased quality of life. This has made the evaluation of Healthy Cities so difficult: it does not follow the usual model of intervention and impact but is constantly weaving new connections and relationships.

\section{LIFE POLITICS}

Healthy Cities was built on the philosophy of the Ottawa Charter for Health Promotion: Health is created where people live, love, work and play. ${ }^{9}$ It aims to widen the health agenda and to generate policy mechanisms that address health determinants. The key question for politics in the 21 st century says Ulrich Beck is "How do we want to live?" 10 The Healthy Cities strategy put communication and visibility for health into its centre - to the extent that it was attacked as being "symbolic politics" only. It transcended the visibility of "modernist" health policy (for example the building of a hospital) towards new strategies for health improvement, which needed new forms of informational politics to be valued and understood. The role of the community and citizens in Healthy Cities is crucial in this respect: Healthy Cities at its core is about democratisation and building community competence for governance. ${ }^{11}$

\section{Strengthen glocal public health}

I believe the time has come for Healthy Cities to become policy relevant in a new way at the global level. Sustainability is lived at the local level, social cohesion is created at the local level, and people's quality of life depends on the quality of their local environment. Healthy Cities has moved far ahead in becoming a highly organised movement but it has not even begun to exploit its potential as a forceful constituency of interest for global health.

Increasingly, the international arena focuses less on governments and their actions but on social institutions, social organisations and networks. The term "regimes" is being used to describe agreed upon principles, norms, and rules, decision making procedures and programmes that govern interaction related to the global commons. ${ }^{12}$ To maintain the internal sovereignty of nation states they tend not to be legally binding and value compliance rather than enforce- ment. Healthy Cities - together with organisations that represent local government-might explore how the Healthy Cities approach can gain recognition within a broader international arena as an accepted regime for health. This could open up innovative procedures that allow for a new type of interaction between existing international institutions and the local level of governance. It could possibly form the nucleus of a global public health alliance based on a broad understanding of health in the context of life politics.

The joint responsibility for the global commons relies on the sustainable action of each and every node of the network. This thinking still is very focused on environmental issues and less on the social and health dimension of development. It has been much easier to define and accept water and air as a global commons than human beings and their health. WHO attempted to move in this direction in the late seventies with its Health For All Strategy, pronouncing health as indivisible and as a human right. Sadly it was ahead of its time and its attempts at bringing countries together around one key area of global social policy was soon counterbalanced by less ambitious approaches. The time seems right to create a new momentum for global health. Because of its unique glocal character, Healthy Cities has every chance of playing a key part in taking up this challenge.

This editorial is based on a Keynote speech presented at the Vienna Healthy Cities Conference, October 1998

Yale University, New Haven, Connecticut, USA

ILONA KICKBUSCH

\footnotetext{
1 Ashton J, Grey P, Barnard K. Healthy Cities-WHO's new public health initiative. Health Promotion 1986;1:319-24.

2 Giddens A. BBC Reith Lectures, 1999. Http://news.bbc.uk

3 Escobar A, ed. Globalism and the politics of place. Development 1998;41.

4 Robertson R. Glokalisierung: homogenitat und heterogenitat in raum und zeit. In: Beck U, ed. Perspektiven der Weltgesellschaft. Frankfurt: AM zeit. In: Beck U, ed. Perspektiven der Weltgesellschaft. Frankfurt: AM
Suhrkamp, 1998:192-220. (English version Robertson R. Globalization or Suhrkamp, 1998:192-220. (English version Robertson R. Glo
glocalization. fournal of International Communications 1994;1.)

5 Reimike W. Global public policy, governing without government. Washington Reimike W. Global public policy, governin
DC: Brookings Institution Press, 1998.

DC: Brookings Institution Press, 1998.
Castels M. End of millennium. Oxford: Blackwell, 1998.

6 Castels M. End of millennium. Oxford: Blackwell, 1998. Smith J, Chatfield C, Pagnucco R. Transnational social movements. New York:
Syracuse, 1997.

8 Lipnack J, Stamps J. The age of the network. New York: Wiley and Sons, 1994. 9 World Health Organisation. Ottawa Charter for Health Promotion. Ottawa: Canadian Public Health Association, 1986.

10 Beck U, Giddens A, Lash S. Reflexive modernization. Cambridge: Polity Press, 1994.

11 Clark D. Healthy cities: a model for community Improvement. Public Management Magazine November 1988:4-8.
}

12 Young OR, ed. Global governance. Cambridge, MA: MIT Press, 1977. 